\title{
Influence of Heat Events on the Composition of Airborne Bacterial Communities in Urban Ecosystems
}

\author{
Zhiguo Fang ${ }^{1, *}$, Weijun Guo ${ }^{1}$, Junwen Zhang ${ }^{1}$ and Xiuqin Lou ${ }^{2}$ \\ 1 School of Environmental Science and Engineering, Zhejiang Gongshang University, Hangzhou 310012, \\ China; mguoweijun@gmail.com (W.G.); zhangjunwen5561@163.com (J.Z.) \\ 2 Hangzhou Center for Disease Control and Prevention, Hangzhou 310021, China; jolly3360@tom.com \\ * Correspondence: zhgfang77@zjgsu.edu.cn; Tel.: +86-571-28008213; Fax: +86-571-28008215
}

Received: 17 August 2018; Accepted: 1 October 2018; Published: 19 October 2018

\begin{abstract}
Airborne bacteria are significantly affected by meteorological and environmental conditions. However, there is little quantitative data available on the effects of these factors on airborne bacteria in urban ecosystems. In the present study, we analyzed weather-dependent changes in the composition of airborne bacterial communities using high throughput sequencing. Samples were collected before and after a period of constant hot weather at four selected sampling sites (YRBS, ZJGUSJC, TJCR, and BLQG) in Hangzhou. Our results show that the average amount of bacterial $16 \mathrm{~S}$ rRNA gene copy numbers per $\mathrm{m}^{3}$ of air decreased significantly after constant high temperature. In addition, the number of operational taxonomic units and the Shannon-Wiener diversity indexes of the samples at all four selected sampling sites were significantly decreased after the heat event, showing notable impact on bacterial diversity. We also detected a significant increase in the abundances of spore-forming bacteria. Firmicutes increased from 3.7\% to 9.9\%, Bacillales increased from $2.6 \%$ to $7.6 \%$, and Bacillaceae increased from $1.5 \%$ to $5.9 \%$. In addition, we observed an increase in beta-Proteobacteria ( $18.2 \%$ to $50.3 \%$ ), Rhodocyclaceae (6.9\% to $29.9 \%$ ), and Burkholderiaceae $(8.1 \%$ to $15.2 \%)$. On the other hand, the abundance of alpha-Proteobacteria (39.6\% to $9.8 \%)$, Caulobacteraceae (17.9\% to $0.5 \%$ ), Sphingomonadaceae $(7.2 \%$ to $3.3 \%)$, and Xanthomonadaceae ( $3.0 \%$ to $0.5 \%$ ) was significantly lower. Taken together, our data suggest that the composition of airborne bacterial communities varies greatly dependent on heat events, and that such communities include several species that are highly susceptible to high-temperature related stressors such as high air temperature, low relative humidity, and high intensity of solar radiation.
\end{abstract}

Keywords: heat events; weather-dependent changes; airborne bacterial communities; bioaerosol

\section{Introduction}

Bioaerosols, which contribute as much as $25 \%$ to the atmospheric aerosols [1], are mixtures of viable and nonviable microbes (e.g., bacteria, fungi, yeasts, and algae) as well as other types of biomass, including a wide range of antigenic compounds, such as dander, plant and insect debris, microbial toxins, and viruses [2]. Bacteria found ubiquitously in the atmosphere, often originating from natural and anthropogenic sources, are the most important biogenic aerosol particles $[1,3]$. A conductive humid environment as well as many human activities, such as waterways and aeration [4-6], wastewater treatment [7,8], composting facilities [9], and solid waste and sewage transport and processing, may enhance the abundance of airborne bacteria in urban environments [10]. Exposure to bacterial aerosols is associated with a wide array of adverse health effects, and many bacterial pathogens such as Streptococcus pneumoniae, Streptococcus pyogenes, Mycoplasma pneumoniae, Haemophilus influenzae, Klebsiella pneumoniae, Pseudomonas aeruginosa, and Mycobacterium tuberculosis are often found in the air [11]. Apart from these pathogens, airborne microbial components (e.g., 
endotoxins, mycotoxins, and glucans) may also strongly influence human health and elicit allergic or inflammatory responses [11-13]. Furthermore, elevated bacterial concentration in the air is closely associated with the increasing probability of food pollution, deterioration of cosmetics and medicine, and corrosion of metallic materials for infrastructure [14,15].

These adverse effects on human health and direct or indirect influences on urban ecosystems have been driving forward research on airborne bacteria all over the world, and a general trend can be observed in different studies correlating the composition of bacterial communities and impact factors including meteorological conditions, environmental conditions, atmospheric composition, seasonality, anthropogenic influences, and variability in bacterial sources [3,11,15-23]. Jang et al. (2018) reported that heavy rainfall significantly affected the composition of airborne bacteria, and the abundances of airborne Propionibacteriaceae always increased after rainfall, whereas those of airborne Firmicutes consistently decreased [16]. In Milan (Italy), summer communities differed less from each other than the communities sampled during other seasons, since the stressors in summer, such as ozone, drought, and solar radiation all together induce a constant selective pressure leading consistently to the survival of adapted species [17]. At a set location, the wind, temperature, precipitation, and season affect the contribution of different source environments for airborne bacteria $[3,18]$. In Hong Kong, bioaerosol pollutants exhibited a strong seasonal trend related to general climatic variables, and were not significantly impacted by the level of urban development [19]. In urban environments, the composition of airborne bacteria in different areas is strongly affected by factors such as traffic conditions, human activities, and vegetation coverage [15]. Gao et al. (2016) reported the varying inter-relationship between the concentration and diameter of culturable bioaerosols and twelve factors in Beijing, and indicated that $\mathrm{SO}_{2}$ and $\mathrm{NO}_{2}$ show positive and negative correlations with culturable bioaerosol concentrations in the morning/evening and mid-day, respectively [20]. Recently, a number of studies have focused on bioaerosol composition during hazy and foggy days in China, due to heavy air pollution and frequent haze events [24-27]. However, the impact of heat event on airborne microbial communities remains poorly investigated.

China, like other places around the world, has experienced a significant warming trend since the mid-1980s. This trend is particularly pronounced in Southeast China, which has experienced a number of extreme heat events in recent years. Prolonged exposure to extremely high temperatures can lead to well documented health issues and has negative effects on many plant and animal species [28]. It may also lead to a lethal effects on bacterial physiology and structure $[29,30]$. The study of airborne bacterial communities during heat events is therefore especially important. Therefore, we chose Hangzhou as a model urban ecosystem to measure the changes in the composition of airborne bacterial communities before and after periods of extreme heat during the summer of 2013 in Zhejiang Province, Southeast China. Hangzhou, the capital and largest city of Zhejiang Province in China, has a subtropical monsoon climate, and is warm in the winter and hot in the summer with four distinctive seasons and abundant precipitation. The main objective of this study was to explore how extreme high temperature events influence the composition airborne bacterial communities, in particular, in the southeast urban area of China. We chose high-throughput sequencing of the $16 \mathrm{~S}$ rRNA gene to determine changes in abundances of airborne bacterial species. The findings of this study might help to better understand and predict the structure and impact of airborne bacterial communities during heat events.

\section{Materials and Methods}

\subsection{Selection of Sampling Date}

According to weather forecast from Zhejiang Meteorological Bureau in China (http:// www.zjmb.gov.cn/zjqx/), 22 July 2013 was selected as the date sampling started (beginning the heat event) and 17 August 2013 was chosen as the finial sampling date (end the heat event), since the weather was thunder showers to cloudy on 21 July and cloudy to thunder showers on 18 August. In addition, relatively low air temperature (including 
maximum and minimum) from 1 to 21 July and 18 to 31 August 2013 was also found in Hangzhou. The weather condition of July and August 2013 was obtained from the network of weather report in China (http:/ / www.tianqihoubao.com/lishi/hangzhou/month/201307.html and http://www.tianqihoubao.com/lishi/hangzhou/month/201308.html).

\subsection{Description of Sampling Sites}

Four typical sampling sites were selected for this study based on their urban function: (1) Tianmushan and Jiaogong Cross Road (TJCR) $\left(30^{\circ} 16^{\prime} 17^{\prime \prime} \mathrm{N}, 120^{\circ} 8^{\prime} 12^{\prime \prime} \mathrm{E}\right)$, a heavily trafficked intersection located in Xihu district about $3 \mathrm{~km}$ from the city center; (2) Zhejiang Gongshang University Jiaogong Campus (ZJGSUJC) $\left(30^{\circ} 17^{\prime} 7^{\prime \prime} \mathrm{N}, 120^{\circ} 8^{\prime} 20^{\prime \prime} \mathrm{E}\right)$, a cultural and educational area situated in Xihu district about $4 \mathrm{~km}$ from the city center; (3) Yan'an Road Business Street (YRBS) (30 $15^{\prime} 45^{\prime \prime} \mathrm{N}$, $\left.120^{\circ} 9^{\prime} 50^{\prime \prime} \mathrm{E}\right)$, a commercial area and business district located at the center of Hangzhou city and in Xiacheng district; and (4) Breeze-ruffled Lotus at Quyuan Garden (BLQG) $\left(30^{\circ} 14^{\prime} 55^{\prime \prime} \mathrm{N}, 120^{\circ} 7^{\prime} 57^{\prime \prime} \mathrm{E}\right)$, a scenic tourist area situated in Xihu district near West Lake, about $5 \mathrm{~km}$ from the city center. Detailed information about these selected sites can be found in Table 1 .

Table 1. Detailed information of the four selected sampling sites in Hangzhou.

\begin{tabular}{|c|c|c|c|c|}
\hline $\begin{array}{l}\text { Sampling } \\
\text { Sites }\end{array}$ & Functional Type & Architecture Type & Vehicle and Personnel Flow & $\begin{array}{l}\text { Vegetation } \\
\text { Coverage }\end{array}$ \\
\hline TJCR & $\begin{array}{l}\text { Heavy traffic } \\
\text { intersection }\end{array}$ & $\begin{array}{l}\text { High and low office } \\
\text { buildings, hotels, and, } \\
\text { main traffic road }\end{array}$ & $\begin{array}{l}\text { Approximately } 180 \text { vehicles per minute, } \\
\text { and } 30 \text { persons per minute }\end{array}$ & $\begin{array}{c}\text { Less than } 5 \\
\text { percent }\end{array}$ \\
\hline ZJGSUJC & $\begin{array}{l}\text { Cultural and } \\
\text { educational area }\end{array}$ & $\begin{array}{l}\text { Experimental buildings, } \\
\text { classrooms, student } \\
\text { dormitory, and office } \\
\text { buildings around }\end{array}$ & $\begin{array}{l}\text { Few vehicles and approximately } 10 \\
\text { persons per minute and the number of } \\
\text { about } 100 \text { persons per minute off class }\end{array}$ & $\begin{array}{l}\text { About } \\
50 \text { percent }\end{array}$ \\
\hline YRBS & $\begin{array}{l}\text { Commercial area } \\
\text { and business } \\
\text { district }\end{array}$ & $\begin{array}{l}\text { Mall and many shopping } \\
\text { buildings around }\end{array}$ & $\begin{array}{l}\text { Approximately } 60 \text { vehicles per minute } \\
\text { and } 80 \text { persons per minute }\end{array}$ & $\begin{array}{l}\text { Less than } \\
5 \text { percent }\end{array}$ \\
\hline BLQG & Scenic tourist area & No buildings around & Few vehicles and personnel & $\begin{array}{l}\text { More than } \\
95 \text { percent }\end{array}$ \\
\hline
\end{tabular}

\subsection{Sample Collection}

Air samples from selected sampling sites were collected using an air biocollector Coriolis $\mu$ air sampler (Bertin Technologies, Montigny-le-Bretonneux, France) presenting a cut-off size (d50) of $0.5 \mu \mathrm{m}$. The Coriolis $\mu$ air sampler is a continuous and high volume aerosol collection system, and the air is drawn into a conical vial in a whirling-type motion using suction. Airborne particles are pulled against the wall by centrifugal force, and are separated from the air and collected in a liquid medium. Samples of airborne bacteria were collected on a platform at a height of $1.5 \mathrm{~m}$. Samples were collected in a sterile solution of $15 \mathrm{~mL}$ Tween 20 (Sigma, St. Louis, MO, USA) at 0.005\% in milliQ water, and each sampling was carried out for $1.5 \mathrm{~h}$ at a calibrated flow rate of $0.25 \mathrm{~m}^{3} \mathrm{~min}^{-1}$ to obtain a total air sample volume of $22.5 \mathrm{~m}^{3}$. Due to evaporation, there are sample liquid losses at this flow rate. Therefore, the sterile solution was added up to $15 \mathrm{~mL}$ every $10 \mathrm{~min}$ during the sampling time. Sampling at the four selected sampling sites was conducted simultaneously with four Coriolis $\mu$ air samplers, and triplicate samples were taken from each selected sampling site at each date. The sampler head plate was thoroughly swabbed with $70 \%$ ethanol between sampling. Samples were stored on ice after sampling.

\subsection{Sample Concentration and DNA Extraction}

Bacterial DNA extraction was performed by using QIAamp DNA Mini Kit (Qiagen, Hilden, Germany) according to the manufacturer's instructions. In brief, samples were collected in $0.5 \% \mathrm{NaCl}$ and transferred into a $15 \mathrm{~mL}$ sterile tube then centrifuged at $14,000 \times g$ for $10 \mathrm{~min}$. The supernatant 
was concentrated using an Amicon Ultra Centrifugal Filter, Ultracel-100K (Billerica, MA, USA), and the final concentrated solute $(60 \mu \mathrm{L})$ was mixed with the cell pellets collected in the first step. After resuspension, total DNA was extracted according to the instruction of isolation of genomic DNA from Gram-positive bacteria.

\subsection{Quantitative PCR}

The abundance of airborne bacteria was estimated by quantification of the copy number of the 16S rRNA gene. A 466 bp fragment of the bacterial 16S rDNA (331-797 according to Escherichia coli position, V3 and V4 hypervariable regions) was PCR-amplified with a universal primer set. The PCR was performed in a total volume of $30 \mu \mathrm{L}$ reactions containing $15 \mu \mathrm{L}$ of $2 \times$ SYBR $^{\circledR}$ Green PCR Master Mix (Life Technologies, Carlsbad, CA, USA), 0.5 M Betaine (Sigma-Aldrich, Saint Louis, MO, USA), and V3-V4 specific $16 \mathrm{~S}$ rRNA gene primers. The amplification was carried out under the following conditions $95{ }^{\circ} \mathrm{C}$ for $10 \mathrm{~min}$, followed by 40 cycles of $95^{\circ} \mathrm{C}$ for $30 \mathrm{~s}, 55^{\circ} \mathrm{C}$ for $45 \mathrm{~s}, 72{ }^{\circ} \mathrm{C}$ for $45 \mathrm{~s}$, followed by a melt curve analysis to ensure that primer-dimers were excluded from the analysis. Standard DNA dilution series were assayed in triplicate, and thermal cycling, data acquisition and analyses were carried out on an Applied Biosystems 7500 Real-Time PCR System with ABI 7500 Software v2.0.6 (Life Technologies, Carlsbad, CA, USA). To determine if the sample curves were significantly different from one another, the linear regression between $\mathrm{Ct}$ values versus $\log _{10}$ copies for each of four sets of standards was analyzed and compared to one another using the one-way analysis of variation (ANOVA) and the Bonferroni's multiple comparisons test in GraphPad Prism5 software (GraphPad Software, San Diego, CA, USA).

\subsection{PCR Amplification and Illumina Miseq PE300 Sequencing}

The V3-V4 regions of the 16S rRNA gene were PCR-amplified for Illumina Miseq PE300 sequencing. Amplicon PCR was performed in $25 \mu \mathrm{L}$ volume reactions with $12.5 \mu \mathrm{L}$ of $2 \times$ KAPA HiFi HotStart ReadyMix, $2.5 \mu \mathrm{L}$ of microbial DNA, and $5 \mu \mathrm{L}$ of each primer (Klindworth et al., 2013) using primers $341 \mathrm{~F}$ (CCTACGGGNGGCWGCAG) and $805 \mathrm{R}$ (GACTACHVGGGTATCTAATCC). Cycling conditions were as follows initial denaturation at $95{ }^{\circ} \mathrm{C}$ for $3 \mathrm{~min}, 25$ cycles at $95{ }^{\circ} \mathrm{C}$ for $30 \mathrm{~s}, 55^{\circ} \mathrm{C}$ for $30 \mathrm{~s}$ and $72{ }^{\circ} \mathrm{C}$ for $30 \mathrm{~s}$, and a final extension at $72{ }^{\circ} \mathrm{C}$ for $5 \mathrm{~min}$. At the $5^{\prime}$ end of the $341 \mathrm{~F}$ primer, one of eight $8 \mathrm{bp}$ barcodes was added to allow sample pooling and subsequent sequence sorting. The amplified products of $550 \mathrm{bp}$ were purified with AMPure XP beads to exclude free primers and primer dimer species. Index PCR was performed in $50 \mu \mathrm{L}$ volume reactions with $25 \mu \mathrm{L}$ of $2 \times \mathrm{KAPA}$ HiFi HotStart ReadyMix, $5 \mu \mathrm{L}$ of DNA, $5 \mu \mathrm{M}$ of primer 1 , and index primer $(8 \mathrm{bp}$ barcodes). Cycling conditions were as follows initial denaturation at $95^{\circ} \mathrm{C}$ for $3 \mathrm{~min} ; 8$ cycles at $95^{\circ} \mathrm{C}$ for $30 \mathrm{~s}, 62{ }^{\circ} \mathrm{C}$ for $30 \mathrm{~s}$, and $72{ }^{\circ} \mathrm{C}$ for $30 \mathrm{~s}$ and a final extension at $72{ }^{\circ} \mathrm{C}$ for $5 \mathrm{~min}$. DNA quantity and purity was evaluated spectrophotometrically using NanoDrop 2000 (Thermo Scientific, Waltham, MA, USA), and the DNA samples were sequenced at XY Biotechnology Co. Ltd. (Shanghai, China) using paired-end sequencing on a Illumina MiSeq PE300 platform.

\subsection{Sequence Analysis}

QIIME v.1.8.0 software (Caporaso et al., Denver, CO, USA) was used to trim all pyrosequencing reads. After trimming, the reads that were shorter than $200 \mathrm{bp}$, contained mismatches and ambiguous bases $(\mathrm{N})$ in primer, or exhibited a homopolymer longer than $10 \mathrm{bp}$ were removed. All samples were normalized to the same sequencing depth using Mothur v.1.30.1 software (Schloss et al., Washtenaw, MI, USA). The operational taxonomic units (OTUs) were clustered with a 97\% similarity cutoff using Usearch v. 5.2.236 (Edgar, Tiburon, CA, USA), and the chimeric sequences were identified and removed using UCHIME v. 4.2.40 (Edgar et al., Tiburon, CA, USA). The Alpha diversity of samples, mainly of the Shannon index, were determined using Mothur v.1.30.1. Taxonomic classification at the phylum and genus level was performed using the Ribosome Database Project (RDP) algorithm to classify the representative sequences of each operational taxonomic unit (OTU). The relative abundance of 
each phylum, class, order, family, and genus was calculated by comparing the number of sequences classified as the phylum, class, order, family, and genus to the number of total bacterial 16S rDNA gene sequences detected per sample.

\subsection{Statistical Analysis}

All experimental data were analyzed with Excel 2010 and SPSS Version 19.0 (Standard Version, SPSS Inc., Chicago, IL, USA), and one-way analysis of variance (ANOVA). The significance level was set to 0.05 .

\section{Results}

\subsection{Weather Conditions during Sampling}

Hangzhou had 18 sunny days, three sunny to cloudy days, two cloudy to sunny days, and four cloudy days with no rainy days from 22 July to 17 August 2013 (Figure 1). The average maximum and minimum air temperatures daily between 22 July 2013 and 17 August 2013 were 39.1 and $29.0^{\circ} \mathrm{C}$, respectively. Over this period, maximum temperatures during the day varied between 41 (one day), 40 (14 days), 39 (four days), 38 (five days), 37 (one day), and $36{ }^{\circ} \mathrm{C}$ (two days). However, the average maximum and minimum air temperatures daily were 36.4 and $27.2^{\circ} \mathrm{C}$, respectively, from 1 July to 21 July, and 33.4 and $26.4{ }^{\circ} \mathrm{C}$ from 18 August to 31 August, respectively, significantly lower than during the high temperature period.

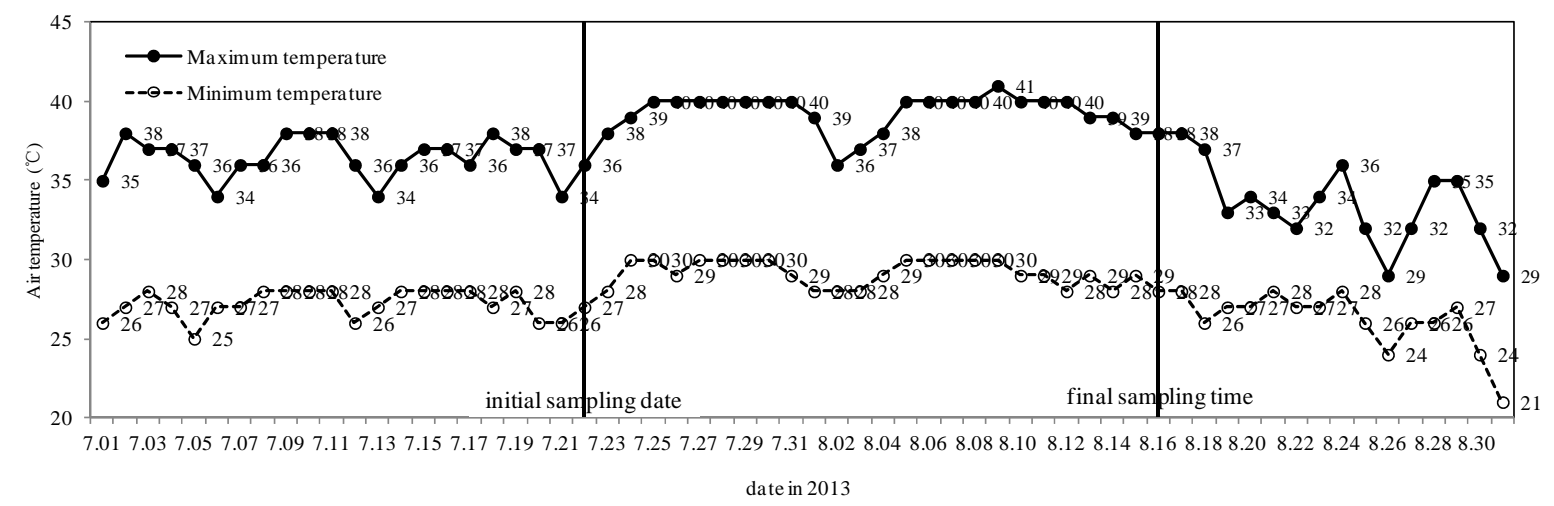

Figure 1. Air temperature chart of Hangzhou during July and August in 2013.

\section{2. $16 S$ rRNA Gene Analysis of Airborne Bacteria}

The abundance of airborne bacteria was estimated by the quantification of the number of $16 \mathrm{~S}$ rRNA gene copies. Airborne bacteria from four selected sampling sites before and after a period of extreme heat were quantified by total DNA extracts. The standard curve was linear from $2 \times 10^{0}$ to $2 \times 10^{5}$ gene copies per reaction $\left(\mathrm{r}^{2}=0.998\right)$. Averages of $7.9 \times 10^{3}$ and $8.8 \times 10^{2}$ bacterial $16 \mathrm{~S}$ rRNA gene copies per $\mathrm{m}^{3}$ of air were determined on 22 July 2013 and 17 August 2013, respectively, and significantly higher 16S rRNA gene copy numbers were detected after the heat event $(p<0.01)$ (Figure 2). The bacterial 16S rRNA gene copy numbers were approximately $6.5 \times 10^{3}, 9.5 \times 10^{3}$, $1.2 \times 10^{4}$, and $4.0 \times 10^{3}$ per $\mathrm{m}^{3}$ of air at the sampling sites of ZJGSUJC, TJCR, YRBS, and BLQG, respectively, at the start of the heat event. At the end of the heat event, bacterial 16S rRNA gene copy numbers were approximately $4.4 \times 10^{2}, 1.3 \times 10^{3}, 1.5 \times 10^{3}$, and $2.3 \times 10^{2}$ per $\mathrm{m}^{3}$ of air at the sampling sites of ZJGSUJC, TJCR, YRBS, and BLQG, respectively. Taken together, 16S rRNA gene copy numbers at the selected four sampling sites were significantly higher before the heat event $(p<0.01)$.

\subsection{OTUs (Operational Taxonomic Units) and Shannon-Wiener Diversity Index}

Number of OTUs and Shannon-Wiener indexes of the analyzed airborne bacterial communities before and after the heat event are shown in Figure 3. For all four selected sampling sites, 
OTUs numbers and Shannon-Wiener indexes were significantly higher before the period of extreme heat $(p<0.05)$, indicating that bacterial diversity was reduced after extreme weather.

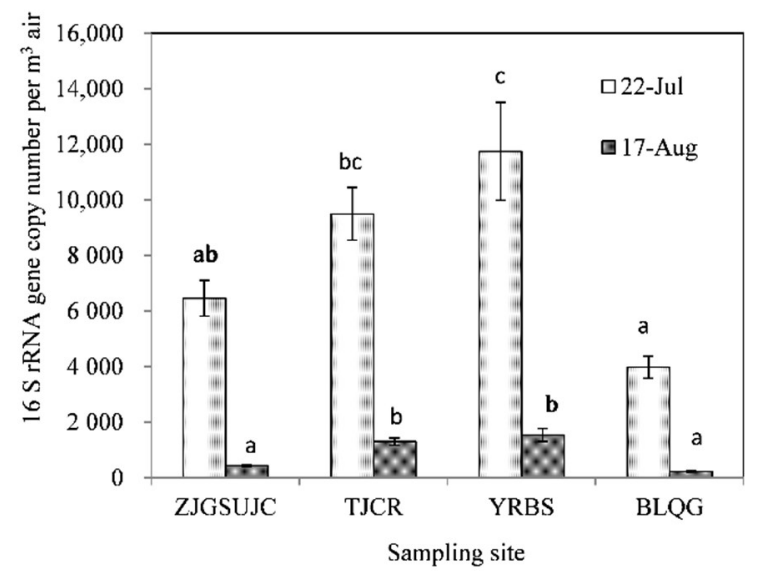

Figure 2. Airborne bacterial 16S rRNA gene copies as determined by quantitative real-time PCR beginning and end the heat event at four selected sampling sites in Hangzhou.

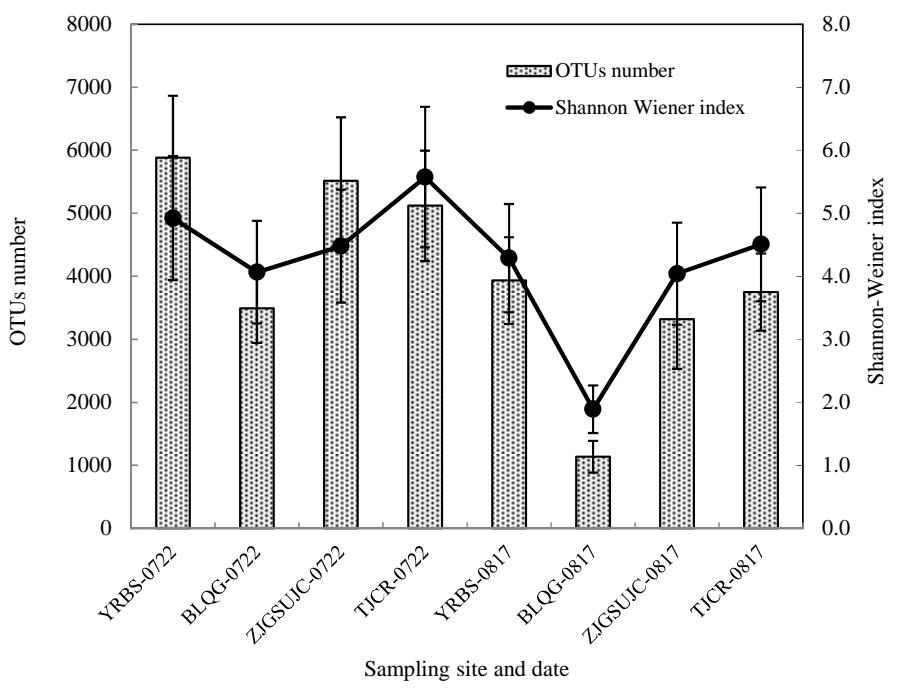

Figure 3. OTUs and Shannon-Wiener index of airborne bacteria before and after heat events.

\subsection{Abundance of Bacterial Phyla in Airborne Bacterial Communities}

Overall, we observed that the air samples collected on prior to the heat event (22 July 2013) were dominated by Proteobacteria $(67.1 \%)$, Actinobacteria $(18.4 \%)$, Deinococcus-Thermus $(4.1 \%)$, Firmicutes $(3.7 \%)$, and Bacteroidetes $(2.8 \%)$. In contrast, the predominant bacterial phyla of the samples collected after the heat event (17 August 2013) were Proteobacteria (65.1\%), Actinobacteria (15.1\%), Firmicutes (9.9\%), Deinococcus-Thermus (3.9\%), and Bacteroidetes (2.9\%). Compared to the samples before the period of extremely high temperature, the proportion of Proteobacteria, Actinobacteria, and Deinococcus-Thermus decreased slightly, while the proportion of spore-forming bacteria such as Firmicutes increased significantly. We also found that the proportion of alpha-Proteobacteria and gamma-Proteobacteria was significantly higher on before the heat event $(p<0.01)$, while the proportion of beta-Proteobacteria was significantly lower $(p<0.01)$. The abundances of alpha-, beta-, and gamma-Proteobacteria were $39.6 \%, 18.2 \%$, and $9.3 \%$ before the heat event, and changed to $9.8 \%$, $50.3 \%$, and $5.0 \%$ after the heat event, respectively (Figure 4 ). 


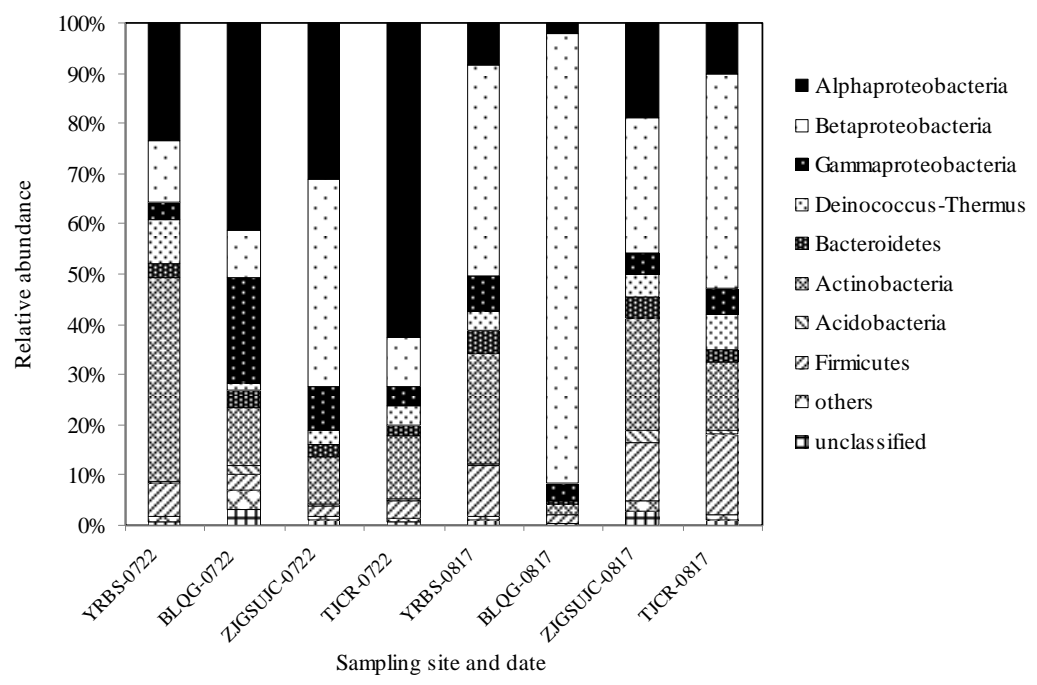

Figure 4. Types and abundance of airborne bacteria at Phylum taxonomic levels before and after heat events.

\subsection{Dominant Bacterial Orders before and after the Heat Event}

The prevalent bacterial groups of air samples collected before the heat event were Caulobacterales $(17.9 \%)$, Actinomycetales (17.7\%), Burkholderiales (10.9\%), Rhizobiales (8.9\%), Sphingomonadales (7.7\%), and Rhodocyclales (6.9\%). After the heat event, Rhodocyclales (29.9\%), Burkholderiales $(19.9 \%)$, Actinomycetales (13.9\%), and Bacillales (7.6\%) were most abundant (Figure 5). Compared to the samples before the period of extreme heat, Burkholderiales, Rhodocyclales, and Bacillales were significantly more abundant after the heat event $(p<0.05)$, and the proportion of Rhodocyclales increased dramatically from $6.9 \%$ to $29.9 \%$, Burkholderiales from $10.9 \%$ to $19.9 \%$, and Bacillales from $2.6 \%$ to $7.6 \%$. In addition, Actinomycetales, Caulobacterales, Rhizobiales, Sphingomonadales, and Xanthomonadales were significantly less abundant after the heat event $(p<0.05)$, and the abundance of Caulobacterales decreased dramatically from $17.9 \%$ to $0.5 \%$, Actinomycetales from $17.7 \%$ to $13.9 \%$, Rhizobiales from $8.9 \%$ to $2.2 \%$, Sphingomonadales from $7.7 \%$ to $3.9 \%$, and Xanthomonadales from $3.1 \%$ to $0.5 \%$.

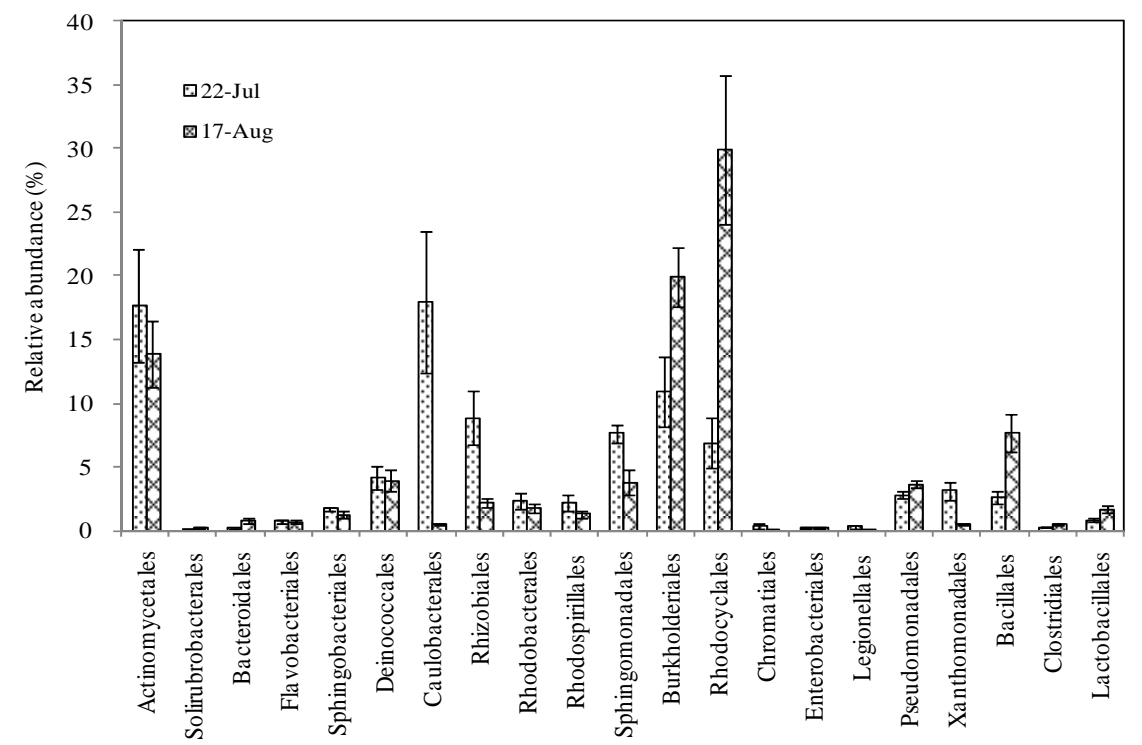

Figure 5. Types and abundance of dominant airborne bacteria at Order taxonomic levels before and after heat events. 


\subsection{Bacterial Families Differentiate after a Period of Extreme Heat}

In general, the predominant bacterial families before the heat event were Caulobacteraceae (17.9\%), Burkholderiaceae (8.1\%), Sphingomonadaceae (7.2\%), Rhodocyclaceae (6.9\%), Deinococcaceae (4.0\%), and Xanthomonadaceae (3.0\%). After the heat event, Rhodocyclaceae (29.9\%), Burkholderiaceae (15.2\%), Bacillaceae (5.9\%), Deinococcaceae (3.9\%), Sphingomonadaceae (3.3\%), and Comamonadaceae $(2.7 \%)$ were prevalent (Table 2). Compared to the samples before the period of extremely high temperature, we detected a significantly higher proportion of Bacillaceae, Burkholderiaceae, Comamonadaceae, Moraxellaceae, and Rhodocyclaceae at 17 August $2013(p<0.05)$, and the proportion of Rhodocyclaceae increased from $6.9 \%$ to $29.9 \%$, Burkholderiaceae from $8.1 \%$ to $15.2 \%$, Bacillaceae from $1.5 \%$ to $5.9 \%$, Comamonadaceae from $1.5 \%$ to $2.7 \%$, and Moraxellaceae from $1.5 \%$ to $2.4 \%$. In contrast, we detected a significantly lower proportion of Bradyrhizobiaceae, Caulobacteraceae, Micrococcaceae, Rhodospirillaceae, Sphingomonadaceae, and Xanthomonadaceae after the heat event $(p<0.05)$, and the proportion of Caulobacteraceae decreased dramatically from $17.9 \%$ to $0.5 \%$, Sphingomonadaceae from $7.2 \%$ to $3.3 \%$, Xanthomonadaceae from $3.0 \%$ to $0.5 \%$, Micrococcaceae from $2.8 \%$ to $1.3 \%$, Rhodospirillaceae from $1.4 \%$ to $0.3 \%$, and Bradyrhizobiaceae from $1.3 \%$ to $0.1 \%$. Finally, Microbacteriaceae (from 1.9\% to 1.2\%) and Rhodobacteraceae (from 2.4 to $1.8 \%$ ) were slightly less abundant.

Table 2. Types and abundance of airborne bacteria at Family taxonomic levels before and after heat events.

\begin{tabular}{|c|c|c|c|c|c|c|c|c|}
\hline \multirow{2}{*}{ Bacterial Groups } & \multicolumn{2}{|c|}{ YRBS } & \multicolumn{2}{|c|}{ BLQG } & \multicolumn{2}{|c|}{ ZJGSUJC } & \multicolumn{2}{|c|}{ TJCR } \\
\hline & $-0722(\%)$ & $-0817(\%)$ & $-0722(\%)$ & $-0817(\%)$ & $-0722(\%)$ & $-0817(\%)$ & $-0722(\%)$ & $-0817(\%)$ \\
\hline Acetobacteraceae & 0.90 & 0.80 & 0.62 & 0.10 & 0.77 & 1.79 & 0.76 & 1.29 \\
\hline Acidobacteria & 0.30 & 0.42 & 2.01 & 0.14 & 0.50 & 2.30 & 0.41 & 0.65 \\
\hline Aerococcaceae & 0.19 & 0.15 & 0.08 & 0.01 & 0.01 & 0.10 & 0.24 & 0.26 \\
\hline Alcaligenaceae & 0.02 & 0.03 & 0.81 & 0.00 & 0.04 & 0.01 & 0.04 & 0.06 \\
\hline Alcanivoracaceae & 0.00 & 0.00 & 1.94 & 0.01 & 0.00 & 0.00 & 0.00 & 0.00 \\
\hline Alteromonadaceae & 0.02 & 0.03 & 0.07 & 0.01 & 0.00 & 0.01 & 0.02 & 0.05 \\
\hline Bacillaceae & 2.86 & 4.09 & 1.20 & 1.10 & 0.50 & 6.71 & 1.38 & 11.51 \\
\hline Bradyrhizobiaceae & 0.25 & 0.10 & 1.12 & 0.05 & 1.42 & 0.24 & 2.32 & 0.10 \\
\hline Burkholderiaceae & 4.95 & 13.76 & 3.24 & 26.79 & 19.96 & 8.23 & 4.11 & 12.03 \\
\hline Caulobacteraceae & 7.37 & 0.41 & 3.50 & 0.06 & 16.11 & 0.96 & 44.69 & 0.51 \\
\hline Chitinophagaceae & 0.34 & 0.56 & 1.04 & 0.07 & 0.85 & 1.28 & 0.50 & 0.52 \\
\hline Comamonadaceae & 0.83 & 2.87 & 1.19 & 3.38 & 2.88 & 2.21 & 1.21 & 2.40 \\
\hline Corynebacteriaceae & 1.24 & 1.37 & 0.25 & 0.12 & 0.65 & 0.81 & 0.51 & 0.76 \\
\hline Cytophagaceae & 1.31 & 0.41 & 0.33 & 0.09 & 0.55 & 0.82 & 0.48 & 0.36 \\
\hline Deinococcaceae & 8.50 & 4.07 & 1.22 & 0.18 & 2.83 & 4.19 & 3.58 & 7.00 \\
\hline Dermabacteraceae & 1.26 & 0.82 & 0.20 & 0.02 & 0.04 & 0.24 & 0.20 & 0.16 \\
\hline Dietziaceae & 0.30 & 0.20 & 0.18 & 0.04 & 0.03 & 0.13 & 0.08 & 0.34 \\
\hline Enterobacteriaceae & 0.12 & 0.48 & 0.44 & 0.08 & 0.21 & 0.26 & 0.13 & 0.20 \\
\hline Erythrobacteraceae & 0.89 & 0.75 & 0.17 & 0.01 & 0.40 & 0.50 & 0.16 & 0.37 \\
\hline Flavobacteriaceae & 0.65 & 1.11 & 1.04 & 0.12 & 0.40 & 0.88 & 0.64 & 0.48 \\
\hline Geodermatophilaceae & 1.18 & 0.20 & 0.07 & 0.00 & 0.32 & 0.50 & 0.16 & 0.19 \\
\hline Hyphomicrobiaceae & 0.39 & 0.15 & 0.47 & 0.02 & 0.92 & 0.27 & 1.96 & 0.14 \\
\hline Intrasporangiaceae & 1.09 & 0.75 & 0.19 & 0.00 & 0.03 & 0.27 & 0.23 & 0.58 \\
\hline Kineosporiaceae & 0.17 & 0.17 & 0.09 & 0.00 & 0.20 & 0.75 & 0.18 & 0.15 \\
\hline Lactobacillaceae & 0.54 & 0.85 & 0.15 & 0.08 & 0.15 & 0.38 & 0.29 & 0.91 \\
\hline Legionellaceae & 0.00 & 0.03 & 1.17 & 0.00 & 0.01 & 0.01 & 0.02 & 0.02 \\
\hline Methylobacteriaceae & 1.92 & 0.92 & 0.91 & 0.87 & 1.24 & 1.53 & 0.84 & 1.04 \\
\hline Microbacteriaceae & 3.17 & 1.26 & 1.09 & 0.15 & 1.10 & 2.34 & 2.19 & 1.03 \\
\hline Micrococcaceae & 9.76 & 2.79 & 0.71 & 0.11 & 0.29 & 1.09 & 0.53 & 0.99 \\
\hline Moraxellaceae & 1.75 & 3.61 & 0.84 & 1.68 & 2.07 & 1.57 & 1.18 & 2.51 \\
\hline Nocardiaceae & 0.10 & 0.09 & 1.09 & 0.02 & 0.13 & 0.07 & 0.21 & 0.20 \\
\hline Nocardioidaceae & 1.36 & 0.89 & 1.65 & 0.13 & 1.32 & 2.84 & 1.97 & 0.89 \\
\hline Oxalobacteraceae & 0.76 & 0.92 & 0.48 & 0.11 & 0.75 & 1.04 & 0.42 & 1.31 \\
\hline Propionibacteriaceae & 1.99 & 1.25 & 0.51 & 0.23 & 0.24 & 1.42 & 0.52 & 1.15 \\
\hline Pseudomonadaceae & 0.77 & 1.46 & 2.81 & 1.13 & 1.09 & 1.28 & 0.49 & 1.29 \\
\hline Rhodobacteraceae & 5.41 & 2.33 & 1.03 & 0.11 & 1.29 & 2.68 & 1.69 & 1.97 \\
\hline Rhodocyclaceae & 5.16 & 23.40 & 2.38 & 58.34 & 16.49 & 13.30 & 3.45 & 24.62 \\
\hline Rhodospirillaceae & 0.32 & 0.23 & 4.61 & 0.02 & 0.37 & 0.56 & 0.27 & 0.25 \\
\hline Sphingomonadaceae & 4.93 & 1.80 & 10.90 & 0.64 & 6.19 & 7.53 & 6.71 & 3.36 \\
\hline Staphylococcaceae & 1.36 & 2.13 & 0.28 & 0.16 & 0.36 & 0.91 & 0.57 & 0.69 \\
\hline Streptococcaceae & 0.47 & 0.73 & 0.16 & 0.03 & 0.12 & 0.27 & 0.14 & 0.33 \\
\hline Streptomycetaceae & 0.77 & 0.08 & 0.05 & 0.02 & 0.04 & 0.62 & 0.24 & 0.17 \\
\hline Xanthomonadaceae & 0.49 & 0.62 & 5.43 & 0.24 & 4.47 & 0.48 & 1.72 & 0.58 \\
\hline Others & 23.85 & 20.94 & 42.28 & 3.53 & 12.65 & 26.59 & 12.55 & 16.60 \\
\hline
\end{tabular}




\section{Discussion}

Our results showed that the heat event in Hangzhou significantly affected the composition of the airborne bacterial communities. During the heat event with no rainy day from 22 July 2013 to 17 August 2013, the weather of Hangzhou was characterized by high air temperature, low relatively humidity, and high intensity of solar radiation at the atmosphere. Airborne bacteria have different distribution regarding their optimal living temperatures, and air temperature can promote or restrain bacterial release and growth. With an analogous function such as temperature, relative humidity has a significant impact on airborne bacterial diversity and composition, and effects combining with temperature are most likely to be produced. Additionally, solar radiation may provide an unfavorable condition for the growth and survival of airborne bacteria and can kill these bacteria because of the microbicidal efficacy of UV [31]. Many studies also confirmed that bacterial communities in the air were strongly affected by those meteorological factors. Zhen et al. (2017) reported that meteorological factors such as air temperature, relative humidity, etc. had more impact on airborne bacterial communities than air pollutants [32]. In Upper Silesia, Poland, the most important meteorological factors related to the viability of airborne bacteria were temperature, UV radiation, and relative humidity [33]. It was also reported that the significant influences on airborne bacteria and pigment organisms at the rural sites were temperature, relative humidity, solar radiation, etc. [34]. Hoeksma et al. (2015) studied the effects of temperature on Escherichia coli, Enterococcus mundtii, and Mycoplasma synoviae and observed that temperature assuredly had significant influence on bacteria [35]. Mouli er al. (2005) reported that high relative humidity may also reduce the viability of bacteria [36]. Tong et al. (1997 and 1998) reported that high solar radiation had a lethal effect on airborne bacteria, and the degree of lethality correlated with the intensity, time, and wavelength of the light [22,37]. The effect of solar radiation on bacterial survival was also investigated by Tong et al. (1997), and bacteria collected on sunny days were preselected for their survivability [37]. These results show that meteorological factors have significantly positive or negative effects on the bacterial composition in the air. Therefore, bacterial communities in Hangzhou varied greatly after the heat event with the above mentioned weather characteristics.

In the present study, the relative abundances of Firmicutes, Bacillales, and Bacillaceae all increased significantly after the heat event. As we known, Firmicutes, Bacillales, and Bacillaceae have a Gram-positive cell wall structure and many of them can produce spores, which are resistant to desiccation and can survive in extreme environments. Jung et al. (2009) investigated the thermal effects on bacterial bioaerosols of Escherichia coli and Bacillus subtilis, and their results showed that Gram-negative bacteria are more susceptible to damage than Gram-positive bacteria in conditions of thermal stress caused by high surrounding temperature [30]. Ray et al. (1984) reported that Gram-positive cells have a fairly rigid and protective shell membrane wall, which may provide better protection against structural injury than metabolic injury during exposure for short periods at high temperatures [38]. For instance, the cell envelope of Gram-positive bacteria is similar to a thick insulator that protects the cell against changes in the environment, while the Gram-negative bacteria cell envelope acts like a thin insulator, which offers considerably less protection against adverse environmental conditions [39]. Once the environment is not favorable for bacterial growth, the protective mechanisms of some bacteria will be induced, which results in the survival of adapted bacterial species in extreme environments. Such protective mechanisms include DNA repair mechanisms, pigmentation, mechanisms promoting aggregation, and metabolic adaptations to nutrient shortages, which all contribute to survival [40]. Another protective mechanism of bacteria is to enter a nondividing state (dormancy), where bacteria morphologically transform to spores, undergo other cell wall modifications, and slow-down or stop their metabolic activity [41]. These transformations can improve the resistance to physical stressors, which increases the chance of survival in the atmosphere [42]. Similar to our finding that the abundance of Bacillales increases after the heat event, the viable fraction of airborne bacteria often seems to consist mainly of spore-forming bacteria after Asian dust events [43]. Since the atmosphere during an extreme heat event is a very harsh environment for bacteria, it is not surprising that the proportion of spore-forming bacteria that can 
tolerate extreme environments increased sharply, and the relative abundance of Caulobacteraceae decreased significantly after the heat event. However, the relative abundance of Rhodocyclaceae and Burkholderiaceae increased significantly, the impact of the heat event on the viability of those bacteria in the air is not fully clear and should be further studied.

The number of OTUs as well as the Shannon-Wiener indexes of the samples were decreased, which suggested that bacterial diversity at the atmosphere was reduced after the heat event in Hangzhou. Simultaneously, 16S rRNA gene copy numbers at the selected four sampling sites were significantly lower after the heat event. This meant that bacterial concentrations in the air were also dramatically affected by air temperature, relatively humidity, and solar radiation. Higher temperature related to strong ultraviolet radiation are not suitable for the propagation and growth of bacteria and lead to the denaturation and inactivation of proteins. Tang (2009) also showed that temperatures above approximately $24^{\circ} \mathrm{C}$ appeared to universally decrease airborne bacterial survival due to protein inactivation caused by high temperature [44]. Wu et al. (2012) reported that air temperature and relative humidity were correlated with total bacteria and Gram-negative cocci, respectively [45]. It was also demonstrated by Di Giorgio et al. (1996) that air temperature and relative humidity had a positive effect on the viability of airborne bacteria, and bacterial concentration increased with the rise of air temperature and relative humidity in a certain range [46]. At urban, rural and coastal sites, and forest areas, the total amount of airborne bacteria was significantly influenced by relative humidity, and bacterial levels in the air increased with relative humidity [34,47]. Liu et al. (2018) reported that relative humidity etc. was the main factor affecting the diversity of total bacteria and the proportion of pathogenic bacteria [48]. In a desert location, it was observed that bacterial concentrations were reduced at noon when destruction by solar radiation was greatest. The bacterial density in samples sampled with coverage was significantly higher than in those sampled with no coverage, and solar radiation could reduce the amount of bioaerosol generated from soil [49]. Fang et al. (2007) also reported that airborne bacteria were damaged by UV radiation with the gradually increasing radiation [15]. Generally, some bacteria have high abundance at high temperature, some at low, but most of them occurred at moderate values of the air temperature, and appropriate temperature can facilitate the release and growth of bacteria so that it can lead to the increase of bacterial concentration. In our study, a continuous and extreme heat event in Hangzhou had negative effects on the survival of airborne bacteria, and led to a great decrease of bacterial density in the atmosphere.

Finally, many studies also showed that wind speed and direction played an indispensable role in affecting ambient bacterial characteristics [31,50]. In this study, the potential importance of wind direction as an unconstrained factor could also influence the sources and abundance patterns of airborne bacteria. However, our data in the present study are very interesting, and patterns were consistent across four sampling sites even in the absence of full meteorological conditions and, even provided that a lack of information on wind direction is acknowledged as a limitation, the study is still a useful contribution.

\section{Conclusions}

We analyzed the density and composition of airborne bacterial communities at four selected sampling sites (YRBS, ZJGUSJC, TJCR, and BLQG) in Hangzhou before and after a heat event. We drew multiple conclusions from our data: (i) The concentration of bacteria in the atmosphere was greatly affected by constant extremely high temperature, and we observed a significant decrease of, on average, $7.9 \times 10^{3}$ to $8.8 \times 10^{2}$ bacterial $16 \mathrm{~S}$ rRNA gene copies per $\mathrm{m}^{3}$ beginning and end the heat event. (ii) The number of OTUs and the Shannon-Wiener indexes of the samples of airborne bacteria decreased, indicating that bacterial diversity was reduced after extreme weather. (iii) The composition of the airborne bacterial communities varied greatly, and the abundance of spore-forming bacteria increased significantly after the heat event. 
Author Contributions: Conceptualization, Z.F.; Methodology, X.L.; Software, W.G.; Validation, Z.F. and X.L.; Formal Analysis, W.G., J.Z., and X.L.; Data Curation, W.G.; Writing-Original Draft Preparation, Z.F.; Writing-Review and Editing, W.G., J.Z., and X.L.; Visualization, Z.F.; Supervision, Z.F.; Project Administration, Z.F.; Funding Acquisition, Z.F.

Funding: This research was funded by the Project of Zhejiang Natural Science Foundation (LY17D050006), the Project of National Natural Science Foundation of China (No. 81402682), and the Open Fund of State Key Laboratory of Urban and Regional Ecology, Research Center for Eco-Environment Science, Chinese Academy of Sciences (No. SKLURE2015-2-1).

Acknowledgments: The authors thank the graduate students who performed the investigation at the different sampling sites in Hangzhou.

Conflicts of Interest: The authors declare no conflicts of interest.

\section{References}

1. Jaenicke, R. Abundance of cellular material and proteins in the atmosphere. Science 2005, 308, 73. [CrossRef] [PubMed]

2. Peccia, J.; Hernandez, M. Incorporating polymerase chain reaction-based identification, population characterization, and quantification of microorganisms into aerosol science: A review. Atmos. Environ. 2006, 40, 3941-3961. [CrossRef]

3. Jones, A.M.; Harrison, R.M. The effects of meteorological factors on atmospheric bioaerosol concentrations-A review. Sci. Total Environ. 2004, 326, 151-180. [CrossRef] [PubMed]

4. Urbano, R.; Palenik, B.; Gaston, C.J.; Prather, K.A. Detection and phylogenetic analysis of coastal bioaerosols using culture dependent and independent techniques. Biogeosciences 2011, 7, 301-309. [CrossRef]

5. Dueker, M.E.; O’Mullan, G.D.; Juhl, A.R.; Weathers, K.C.; Uriarte, M. Local environmental pollution strongly influences culturable bacterial aerosols at an urban aquatic superfund site. Environ. Sci. Technol. 2012, 46, 10926-10933. [CrossRef] [PubMed]

6. Dueker, M.E.; O'Mullan, G.D. Aeration remediation of a polluted waterway increases near-surface coarse and culturable microbial aerosols. Sci. Total Environ. 2014, 478, 184-189. [CrossRef] [PubMed]

7. Brandi, G.; Sisti, M.; Amagliani, G. Evaluation of the environmental impact of microbial aerosols generated by wastewater treatment plants utilizing different aeration systems. J. Appl. Microbiol. 2010, 88, 845-852.

8. Carducci, A.; Arrighi, S.; Ruschi, A. Detection of coliphages and enteroviruses in sewage and aerosol from an activated sludge wastewater treatment plant. Lett. Appl. Microbiol. 2010, 21, 207-209.

9. Albrecht, A.; Witzenberger, R.; Bernzen, U.; Jackel, U. Detection of airborne microbes in a composting facility by cultivation based and cultivation independent methods. Ann. Agric. Environ. Med. 2007, 14, 81-85. [PubMed]

10. Gangamma, S. Characteristics of airborne bacteria in Mumbai urban environment. Sci. Total Environ. 2014, 488-489, 70-74. [CrossRef] [PubMed]

11. Smets, W.; Moretti, S.; Denys, S.; Lebeer, S. Airborne bacteria in the atmosphere: Presence, purpose, and potential. Atmos. Environ. 2016, 139, 214-221. [CrossRef]

12. Martinez, K.; Rao, C.; Burton, N. Exposure assessment and analysis for biological agents. Grana 2004, 43, 193-208. [CrossRef]

13. Heutte, N.; André, V.; Arvis, C.D.; Bouchart, V.; Lemarié, F.; Legendre, P.; Votier, E.; Louis, M.Y.; Madelaine, S.; Séguin, V.; et al. Assessment of multi-contaminant exposure in a cancer treatment center: A 2-year monitoring of molds, mycotoxins, endotoxins, and glucans in bioaerosols. Environ. Monit. Assess. 2017, 189, 31-44. [CrossRef] [PubMed]

14. Fang, Z.; Yao, W.; Lou, X.; Hao, C.; Gong, C.; Ouyang, Z. Profile and characteristics of culturable bacteria in Hangzhou, southeast of China. Aerosol Air Qual. Res. 2016, 16, 1690-1700. [CrossRef]

15. Fang, Z.G.; Ouyang, Z.Y.; Zheng, H.; Wang, X.K.; Hu, L.F. Culturable airborne bacteria in outdoor environments in Beijing, China. Microb. Ecol. 2007, 54, 487-496. [CrossRef] [PubMed]

16. Jang, G.; Hwang, C.Y.; Cho, B.C. Effects of heavy rainfall on the composition of airborne bacterial communities. Front. Environ. Sci. Eng. 2018, 12, 1-12. [CrossRef]

17. Bertolini, V.; Gandolfi, I.; Ambrosini, R.; Bestetti, G.; Innocente, E.; Rampazzo, G.; Franzetti, A. Temporal variability and effect of environmental variables on airborne bacterial communities in an urban area of Northern Italy. Appl. Microbiol. Biotechnol. 2013, 97, 6561-6570. [CrossRef] [PubMed] 
18. Bowers, R.M.; Clements, N.; Emerson, J.B.; Wiedinmyer, C.; Hannigan, M.P.; Fierer, N. Seasonal variability in bacterial and fungal diversity of the near-surface atmosphere. Environ. Sci. Technol. 2013, 47, 12097-12106. [CrossRef] [PubMed]

19. Woo, A.C.; Brar, M.S.; Chan, Y.; Lau, M.C.Y.; Leung, F.C.C.; Scott, J.A.; Vrijmoed, L.L.P.; Zawar-Reza, P.; Pointing, S.B. Temporal variation in airborne microbial populations and microbially-derived allergens in a tropical urban landscape. Atmos. Environ. 2013, 74, 291-300. [CrossRef]

20. Gao, M.; Yan, Y.; Qiu, T.L.; Han, M.L.; Wang, X.M. Variation of correlations between factors and culturable airborne bacteria and fungi. Atmos. Environ. 2016, 128, 10-19. [CrossRef]

21. Maki, T.; Puspitasari, F.; Hara, K.; Yamada, M.; Kobayashi, F.; Hasegawa, H.; Iwasaka, Y. Variations in the structure of airborne bacterial communities in a down wind area during an Asian dust (Kosa) event. Sci. Total Environ. 2014, 488, 75-84. [CrossRef] [PubMed]

22. Tong, Y.; Lighthart, B. Effect of simulated solar radiation on mixed outdoor atmospheric bacterial populations. FEMS Microbiol. Ecol. 1998, 26, 311-316. [CrossRef]

23. Jeon, E.M.; Kim, H.J.; Jung, K.; Kim, J.H.; Kim, M.Y.; Kim, Y.P.; Ka, J.O. Impact of Asian dust events on airborne bacterial community assessed by molecular analyses. Atmos. Environ. 2011, 45, 4313-4321. [CrossRef]

24. Cao, C.; Jiang, W.; Wang, B.; Fang, J.; Lang, J.; Tian, G.; Jiang, J.; Zhu, T.F. Inhalable microorganisms in Beijing's PM2.5 and PM10 pollutants during a severe smog event. Environ. Sci. Technol. 2014, 48, 1499-1507. [CrossRef] [PubMed]

25. Li, Y.P.; Fu, H.L.; Wang, W.; Liu, J.; Meng, Q.L.; Wang, W.K. Characteristics of bacterial and fungal aerosols during the autumn haze days in Xi'an, China. Atmos. Environ. 2015, 122, 439-447. [CrossRef]

26. Gao, M.; Jia, R.Z.; Qiu, T.L.; Han, M.L.; Song, Y.; Wang, X.M. Seasonal size distribution of airborne culturable bacteria and fungi and preliminary estimation of their deposition in human lungs during non-haze and haze days. Atmos. Environ. 2015, 118, 203-210. [CrossRef]

27. Dong, L.J.; Qi, J.H.; Shao, C.C.; Zhong, X.; Gao, D.M.; Cao, W.W.; Gao, J.W.; Bai, R.; Long, G.Y.; Chu, C.C. Concentration and size distribution of total airborne microbes in hazy and foggy weather. Sci. Total Environ. 2015, 541, 1011-1018. [CrossRef] [PubMed]

28. Baccini, M.; Michelozzi, P. Heat effects on mortality in 15 European cities. Epidemiology 2008, 19, 711-719. [CrossRef] [PubMed]

29. Russell, A.D. Lethal effects of heat on bacterial physiology and structure. Sci. Prog. 2003, 86, 115-137. [CrossRef] [PubMed]

30. Jung, J.H.; Lee, J.E.; Kim, S.S. Thermal effects on bacterial bioaerosols in continuous air flow. Sci. Total Environ. 2009, 407, 4723-4730. [CrossRef] [PubMed]

31. Zhai, Y.B.; Li, X.; Wang, T.F.; Wang, B.; Li, C.T.; Zeng, G.M. A review on airborne microorganisms in particulate matters: Composition, characteristics and influence factors. Environ. Int. 2018, 113, 74-90. [CrossRef] [PubMed]

32. Zhen, Q.; Deng, Y.; Wang, Y.Q.; Wang, X.K.; Zhang, H.X.; Sun, X.; Ouyang, Z.Y. Meteorological factors had more impact on airborne bacterial communities than air pollutants. Sci. Total Environ. 2017, 601-602, 703-712. [CrossRef] [PubMed]

33. Bragoszewska, E.; Pastuszka, J.S. Influence of meteorological factors on the level and characteristics of culturable bacteria in the air in Gliwice, Upper Silesia (Poland). Aerobiologia 2018, 34, 241-255. [CrossRef] [PubMed]

34. Shaffer, B.T.; Lighthart, B. Survey of culturable airborne bacteria at four diverse locations in Oregon: Urban, rural, forest, and coastal. Microb. Ecol. 1997, 34, 167-177. [CrossRef] [PubMed]

35. Hoeksma, P.; Aarnink, A.; Ogink, N. Effects of temperature and relative humidity on the survival of airborne bacteria. Livest. Res. Rep. 2015, 864, 1-27.

36. Mouli, P.C.; Mohan, S.V.; Reddy, S.J. Assessment of microbial (bacteria) concentrations of ambient air at semi-arid urban region: Influence of meteorological factors. Appl. Ecol. Environ. Res. 2005, 3, 139-149. [CrossRef]

37. Tong, Y.; Lighthart, B. A study of the relationship between pigmented outdoor atmospheric bacteria and solar radiation. Photochem. Photobiol. 1997, 65, 103-106. [CrossRef]

38. Ray, B. Reversible freeze-injury. In Repairable Lesions in Microorganisms; Hurst, A., Nasim, A., Eds.; Academic Press: New York, NY, USA, 1984. 
39. Neidhardt, F.C.; Ingraham, J.L.; Schaechter, M. Physiology of the Bacterial Cell: A Molecular Approach: Sinauer Associates Sunderland; Sinauer Associates Inc.: Sunderland, MA, USA, 1990.

40. Tringe, S.G.; Zhang, T.; Liu, X.; Yu, Y.; Lee, W.H.; Yap, J.; Yao, F.; Suan, S.T.; Ing, S.K.; Haynes, M. The airborne metagenome in an indoor urban environment. PLoS ONE 2008, 3, e1862. [CrossRef] [PubMed]

41. Delort, A.M.; Vaïtilingom, M.; Amato, P.; Sancelme, M.; Parazols, M.; Mailhot, G.; Laj, P.; Deguillaume, L. A short overview of the microbial population in clouds: Potential roles in atmospheric chemistry and nucleation processes. Atmos. Environ. 2010, 98, 249-260. [CrossRef]

42. Kobayashi, F.; Maki, T.; Kakikawa, M.; Yamada, M.; Puspitasari, F.; Iwasaka, Y. Bioprocess of Kosa bioaerosols: Effect of ultraviolet radiation on airborne bacteria within Kosa (Asian dust). J. Biosci. Bioeng. 2015, 119, 570-579. [CrossRef] [PubMed]

43. Yamaguchi, N.; Park, J.; Kodama, M.; Ichijo, T.; Baba, T. Changes in the airborne bacterial community in outdoor environments following Asian dust events. Microbes Environ. 2014, 29, 82-88. [CrossRef] [PubMed]

44. Tang, J.W. The effects of environmental parameters on the survival of airborne infectious agents. J. $R$. Soc. Interface 2009, 6, 737-748. [CrossRef] [PubMed]

45. Wu, Y.H.; Chan, C.C.; Chew, G.L.; Shih, P.W.; Lee, C.T.; Chao, H.J. Meteorological factors and ambient bacterial levels in a subtropical urban environment. Int. J. Biometeorol. 2012, 56, 1001-1009. [CrossRef] [PubMed]

46. Di Giorgio, C.; Krempff, A.; Guiraud, H.; Binder, P.; Tiret, C.; Dumenil, G. Atmospheric pollution by airborne microorganisms in the city of Marseilles. Atmos. Environ. 1996, 30, 155-160. [CrossRef]

47. Macher, J.; Huang, F.; Flores, M. A two-year study of microbiological indoor air quality in a new apartment. Arch. Occup. Environ. Health 1991, 46, 25-29. [CrossRef] [PubMed]

48. Liu, H.; Zhang, X.; Zhang, H.; Yao, X.W.; Zhou, M.; Wang, J.Q.; He, Z.F.; Zhang, H.H.; Lou, L.P.; Mao, W.H.; et al. Effect of air pollution on the total bacteria and pathogenic bacteria in different sizes of particulate matter. Environ. Pollut. 2018, 233, 483-493. [CrossRef] [PubMed]

49. Fedorak, P.M.; Westlake, D.W.S. Effect of sunlight on bacterial survival in transparent air samplers. Can. J. Microbiol. 1978, 24, 618-619. [CrossRef] [PubMed]

50. Murata, K.; Zhang, D. Transport of bacterial cells toward the Pacific in northern hemisphere westerly winds. Atmos. Environ. 2014, 87, 138-145. [CrossRef] 